\title{
ANALISIS PENERAPAN STANDAR AKUNTANSI PEMERINTAH BERBASIS AKRUAL DALAM PENYAJIAN LAPORAN KEUANGAN DINAS LINGKUNGAN HIDUP KOTA SAMARINDA TAHUN 2017
}

\author{
Oleh : Dwi Joko Prabowo ${ }^{1}$, Elfreda Aplonia Lau ${ }^{2}$ \\ dan Umi Kulsum ${ }^{3}$
}

${ }^{1}$ Mahasiswa Fakultas Ekonomi UNTAG Samarinda, ${ }^{2}$ dan ${ }^{3}$ Dosen

Fakultas Ekonomi Universitas 17 Agustus 1945 Samarinda umykulsum835@gmail.com

\begin{abstract}
The goal of the study to determine and analyze the presentation of : balance sheet, budget realization report, operational report, equity change report and notes on Samarinda City Environment Department's 2017 financial report and analyzing its compliance with Accrual Based Government Accounting Standards based on PP No.71 of 2010.

Data collection techniques used in this study were interviews, documentation and observation. The analysis technique used is this study is comparative descriptive and presentation according to Jean D. Champion.

The results of the study show that: First, the Balance Sheet presented at the Samarinda City Environment Agency is in the category of very in accordance with PP Number 71 Year 2010. Second, the Budget Realization Report presented at the Samarinda City Environmental Service is in the category very much in accordance with PP Number 71 of 2010. The third Operational Reports presented at the Samarinda City Environmental Agency are categorized according to Government Regulation Number 71 of 2010. Fourth, the Equity Change Report presented at the Samarinda City Environmental Office falls into the category of Government Regulation No. 71 Fifth, 2010. Presentation of posts presented in the Notes to the Financial Statements at the City of Samarinda Environmental Office is in the category of very in accordance with Government Accounting Standards based on PP No.71 of 2010.
\end{abstract}

Keywords: Implementation, Financial Statement,SAP, Accrual Basis 


\section{PENDAHULUAN}

\section{A. Latar Belakang}

Peraturan pemerintah nomor 71 tahun 2010 pasal 1 ayat (3) tentang standar akuntansi pemerintah yang selanjutnya disingkat SAP, merupakan prinsip-prinsip akuntansi yang diterapkan dalam menyusun dan menyajikan laporan keuangan pemerintah. Dalam salah satu penjelasan di Undangundang Perbendaharaan Negara disebutkan bahwa SAP ditetapkan dalam peraturan pemerintah yang diatur dengan PP No. 71 Tahun 2010, salah satu ciri pokok dari perubahan tersebut adalah penggunaan basis akuntansi dari basis kas menjadi basis akrual, dimana basis kas mengakui dan mencatat transaksi pada saat terjadinya penerimaan dan pengeluaran kas dan tidak mencatat aset dan kewajiban, sedangkan basis akrual mengakui dan mencatat transaksi pada saat terjadinya transaksi (baik kas maupun non kas) dan mencatat aset dan kewajiban. Dapat disimpulkan bahwa SAP merupakan persyaratan yang mempunyai kekuatan hukum dalam upaya meningkatkan kualitas laporan keuangan pemerintah di Indonesia.

Diterbitkannya PP No.71 Tahun 2010 tentang SAP yang akan digunakan untuk menghasilkan suatu laporan keuangan yang andal dan dapat dijadikan pijakan dalam pengambilan keputusan dan yang di harapkan dapat menjadi acuan, patokan serta standar untuk diterapkan dalam lingkup pemerintahan, yaitu pemerintah pusat, pemerintah daerah dan satuan organisasi dilingkungan pemerintah pusat/daerah yang wajib untuk menyajikan laporan keuangan agar lebih terciptanya akuntabilitas dan transparansi dari pengelolaan keuangan daerah tersebut. Peraturan ini menjadi pedoman yang harus ditaati oleh setiap Daerah Otonom Kabupaten/Kota maupun Propinsi dalam menyajikan laporan keuangan berbasis akrual pada pemerintah daerahnya. Sejalan dengan akan diterapkannya SAP Berbasis Akrual baik pada Pemerintah Pusat maupun Pemerintah Daerah, dengan direvisinya PP No.24 Tahun 2005 menjadi PP No.71 Tahun 2010 tentang Standar Akuntansi Pemerintah, membawa beberapa perubahan dalam standar dan mekanisme penyajian laporan keuangan di pemerintah untuk menerapkan SAP berbasis akrual dalam penyajian laporan keuangannya.

Laporan keuangan pemerintah daerah berdasarkan PP No 71 tahun 2010 tentang SAP berbasis akrual adalah merupakan laporan yang terstruktur mengenai posisi keuangan dan transaksi-transaksi yang dilakukan oleh suatu entitas pelaporan. Berdasarkan SAP tahun 2010 laporan keuangan pokok terdiri dari laporan realisasi anggaran (LRA), laporan perubahan saldo anggaran lebih (laporan perubahan SAL), neraca, laporan operasional (LO), laporan arus kas (LAK), laporan perubahan ekuitas (LPE) dan catatan atas laporan keuangan (CALK). 
Suksesnya penerapan PP No. 71 Tahun 2010 di sektor publik tentu akan dipengaruhi oleh beberapa faktor diantaranya adalah kualitas sumber daya manusia dan teknologi informasi yang digunakan oleh instansi pemerintah daerah. Apabila dalam sebuah instansi pemerintahan memiliki kualitas sumber daya manusia yang handal serta didukung oleh teknologi informasi itu mampu menjadi modal awal dalam menunjang penerapan PP No. 71 Tahun 2010.

Dinas Lingkungan Hidup Kota Samarinda sebagai instansi pemerintah daerah tentu wajib hukumnya menyelenggarakan laporan keuangan pemerintah daerah berdasarkan PP No 71 tahun 2010 tentang SAP berbasis akrual. Berdasarkan SAP tahun 2010 laporan keuangan pokok terdiri dari laporan realisasi anggaran (LRA), laporan perubahan saldo anggaran lebih (laporan perubahan SAL), neraca, laporan operasional (LO), laporan arus kas (LAK), laporan perubahan ekuitas (LPE) dan catatan atas laporan keuangan (CALK).

Dinas Lingkungan Hidup Kota Samarinda telah menyelenggarakan laporan keuangan merujuk pada peraturan tersebut. Namun penyajian laporan keuangan telah mengikuti atau belum sepenuhnya menerapkan peraturan pemerintah Nomor 71 tahun 2010 tentang standar akuntansi pemerintahan berbasis akrual belum diketahui secara pasti, sehingga perlu dilakukan penelitian ini. Dengan demikian penelitian ini bertujuan untuk mengetahui dan menganalisis penyajian : neraca, laporan realisasi anggaran, laporan operasional, laporan perubahan ekuitas dan catatan atas laporan keuangan Dinas Lingkungan Hidup Kota Samarinda tahun 2017 dan melihat kesesuaiannya dengan Standar Akuntansi Pemerintahan Berbasis Akrual berdasarkan PP No.71 Tahun 2010.

\section{B. Rumusan Masalah}

1. Apakah penyajian neraca Dinas Lingkungan Hidup Kota Samarinda tahun 2017 sudah sesuai dengan Standar Akuntansi Pemerintahan Berbasis Akrual berdasarkan PP No.71 Tahun 2010?

2. Apakah penyajian laporan realisasi anggaran Dinas Lingkungan Hidup Kota Samarinda tahun 2017 sudah sesuai dengan Standar Akuntansi Pemerintahan Berbasis Akrual berdasarkan PP No.71 Tahun 2010 ?

3. Apakah penyajian laporan operasional Dinas Lingkungan Hidup Kota Samarinda tahun 2017 sudah sesuai dengan Standar Akuntansi Pemerintahan Berbasis Akrual berdasarkan PP No.71 Tahun 2010 ?

4. Apakah penyajian laporan perubahan ekuitas Dinas Lingkungan Hidup Kota Samarinda tahun 2017 sudah sesuai dengan Standar Akuntansi Pemerintahan Berbasis Akrual berdasarkan PP No.71 Tahun 2010 ?

5. Apakah penyajian catatan atas laporan keuangan Dinas Lingkungan Hidup Kota Samarinda tahun 2017 sudah sesuai dengan Standar Akuntansi Pemerintahan Berbasis Akrual berdasarkan PP No.71 Tahun 2010 ? 


\section{KERANGKA DASAR TEORI}

Teori yang melandasi penelitian ini adalah akuntansi sektor publik. Akuntansi Sektor Publik yang memiliki perbedaan dengan Akuntansi Sektor Swasta. Hal yang paling mencolok antara Akuntansi Sektor Publik dengan Akuntansi Sektor Swasta terletak pada bagian instansi yang menggunakannya. Akuntansi Sektor Publik biasanya terkait dengan organisasi Pemerintahan Pusat, Pemerintahan Daerah, hingga Pemerintahan Desa.

Akuntansi Sektor Publik oleh Indra Bastian (2010:3) didefinisikan sebagai mekanisme teknik dan analisis akuntansi yang diterapkan pada pengelolaan dana masyarakat di lembaga-lembaga tinggi negara dan department-departement dibawahnya, pemerintah daerah, BUMN, BUMD, LSM, dan yayasan sosial, maupun pada proyek-proyek kerja sama sektor publik serta swasta. Demikian pula Mardiasmo (2009:11) berpendapat bahwa : Akuntansi sektor publik telah mengalami perkembangan yang sangat pesat. Saat ini terdapat akuntansi yang dilakukan oleh lembagalembaga pemerintah, perusahaan milik Negara/daerah, dan berbagai organisasi publik lainnya yang dibandingkan dengan masa-masa sebelumnya. Terdapat tuntutan yang lebih besar dari masyarakat untuk dilakukan transparansi dan akuntabilitas publik oleh lembaga-lembaga publik.

Pendlebury Maurice and Rowan, Jones (2010:2) : The heart of the public sector is the sovereignty ofgovernments ultimately controlledby politicians. For a national government, this sovereignty extends overa wholecountry, including its economy; for a state government within a federation, the sovereignty extends over itsindividual state

\section{Laporan Keuangan Pemerintah Daerah}

Laporan Keuangan Pemerintah Daerah merupakan salah satu wujud bentuk pertanggungjawaban pemerintah daerah atas penggunaan keuangan daerah dalam pelaksanaan otonomi daerah dan operasional pemerintah daerah, hal tersebut menjadi tolak ukur kinerja untuk dapat dipertanggungjawabkan, pada setiap akhir tahun anggaran.

Menurut Peraturan pemerintah Nomor 71 lahun 2010 Laporan Keuangan Pemerintah Daerah adalah :Laporan Keuangan pemerintahan terdiri dari Laporan Pelaksanaan Anggaran (Budgetary report), laporan finansial, dan CaLK. Laporan finansial terdiri dari Neraca, LO, LPE, dab LAK. CaLK merupakan laporan yang merinci atau menjelaskan lebih lanjut atas pos-pos laporan pelaksanaan anggaran maupun laporan finansial dan merupakan laporan yang tidak terpisahkan dari laporan pelaksanaan anggaran maupun laporan finansial. 


\section{Laporan Realisasi Anggaran}

Laporan realisasi anggaran menyajikan ikhtisar sumber, alokasi, dan pemakaian sumber daya keuangan yang dikelola oleh pemerintah pusat/daerah, yang menggambarkan perbandingan antara anggaran dan realisasi dalam satu priode pelaporan.

a. Pendapatan-LRA adalah penerimaan oleh Bendahara Umum Negara/Daerah oleh entitas pemerintah lainya yang menambah saldo Anggaran Lebih dalam periode tahun anggaran yang bersangkutan yang menjadi hak pemerintah, dan tidak perlu dibayar kembali oleh pemerintah.

b. Belanja adalah semua pengeluaran oleh Bendahara Umum Negara/Daerah yang mengurangi Saldo Anggaran Lebih dalam periode tahun anggaran bersangkutan yang tidak akan diperoleh pembayaran kembali oleh pemerintah.

c. Teransfer adalah penerimaan atau pengeluaran uang oleh suatu entitas pelaporan dari/kepada entitas pelaporan lain termasuk dana perimbangan dan dana bagi hasil.

d. Pembiayaan (financing) adalah setiap penerimaan/pengeluaran yang tidak berpengaruh pada kekayaan bersih entitas yang perlu dibayar kembali dan /atau akan diterima kembali, baik pada tahun anggaran bersangkutan maupun tahun-tahun anggaran berikutnya yang dalam penganggaran pemerintah terutama dimaksudkan untuk menutup defisit atau memanfaatkan surplus anggaran

\section{Laporan Perubahan Saldo Anggaran Lebih}

Laporan Perubahan Saldo Anggaran Lebih (LP-SAL) menyajikan pos-pos, yaitu saldo anggaran lebih awal (saldo tahun sebelimnya), penggunaan saldo anggaran lebih, sisa lebih atau kurang pembiayaan anggaran (SILPA/SIKPA) tahun berjalan, koreksi kesalahan tahun sebelumnya, lain-lain dan saldo anggaran lebih akhir untuk periode berjalan. Pos-pos tersebut disajikan secara komperatif dengan periode sebelumnya. LP-SAL dimaksudkan untuk memberi ringkasan atas pemanfaatan saldo anggaran dan pembiayaan pemerintah, sehingga suatu entitas pelaporan harus menyajikan rincian lebih lanjut dari unsur-unsur yang terdapat dalam LP-SAL dalam Catatan atas Laporan Keuangan. Struktur LP-SAL baik pada Pemerintah Pusat, Pemerintah Provinsi dan Pemerintah Kabupaten/Kota tidak memiliki perbedaan.

\section{Neraca}

Neraca menggambarkan posisi keuangan suatu entitas pelaporan mengenai :

a. Asset adalah sumber daya ekonomi yang dikuasai dan/atau dimiliki oleh pemerintah sebagai akibat dari peristiwa masa lalu dan dari mana 
manfaat ekonomi dan/atau sosial dimasa depan diharapkan dapat diperoleh, baik oleh pemerintah maupun masyarakat umum sumbersumber daya yang dipelihar karena alasan budaya dan sejarah.

b. Kewajiban adalah utang yang timbul dari peristiwa masa lalu yang penyelesaiaanya mengakibatkan aliran keluar sumber daya ekonomi pemerintahan.

c. Ekuitas adalah kekayaan bersih pemerintah yang merupakan selisih antara aset dan kewajiban pemerintah.

\section{Laporan Operasional}

Laporan Operasional menyajikan ikhtisar sumber daya ekonomi yang menambahkan ekuitas dan penggunaan yang dikelola oleh pemerintah Pusat/Daerah untuk kegiatan penyelenggaraan pemerintah dalam satu periode pelaporan. Unsur laporan Oprasional terdiri dari :

a. Pendapatan-LO adalah hak pemerintah yang diakui sebagai penambah nilai kekayaan bersih

b. Transfer adalah hak penerima atau kewajiban pengeluaran uang dari atau oleh suatu entitas pelaporan dari atau kepada entitas pelaporan lain, termasuk dana perimbangan dan dana bagi hasil.

c. Pos Luar Biasa adlah pendapatan luar biasa atau beban luar biasa yang terjadi karena kejadian atau transaksi yang bukan merupakan operasi biasa, tidak diharapkan sering atau rutin terjadi, dan berada diluar kendali atau pengaruh entitas bersangkutan.

\section{Laporan Arus Kas}

Laporan Arus Kas menyajikan informasi kas sehubungan dengan aktiva operasi, investasi, pendanaan dan transitoris yang mengambarkan saldo awal, penerimaan pengeluaran dan saldo akhir kas pemerintah pusat/daerah selama periode tertentu. Unsur Laporan Arus Kas terdiri dari : Penerimaan Kas adalah semua aliran yang masuk Bendahara Umum Negara/Daerah. Pengeluaran Kas adalah semua aliran kas yang keluar dari Bendahara Umum Negara/Daerah.

\section{Laporan Perubahan Ekuitas}

Laporan Perubahan Ekuitas menyajikan sekurang-kurangnya pos-pos ekuitas awal atau ekuitas tahun sebelumnya, Surplus atau deficit-LO pada periode bersangkutan dan koreksi-koreksi yang langsung menambah atau mengurangi ekuitas, yang antara lain berasal dari dampak kumulatif yang disebabkan oleh perubahan kebijakan akuntansi dan koreksi kesalahan mendasar, misalnya :

a. Dari persediaan yang terjadi pada periode-periode sebelumnya.

b. Perubahan nilai asset tetap karna revaluasi asset tetap. 
Entitas laporan juga perlu menyajikan rincian lebih lanjut dari unsurunsur yang terdapat pada Laporan Perubahan Ekuitas yang dijelaskan pada Catatan atas Laporan Keuangan. Struktur Laporan Perubahan Ekuitas baik pada Pemerintah Pusat, Pemerintah Provinsi dan Pemerintah Kabupaten/Kota tidak memiliki perbedaan.

\section{Catatan atas laporan Keuangan}

Catatan atas Laporan Keuangan meliputi penjelasan naratif dan rincian dari angka yang tertera dalam Laporan Realisasi Anggaran, Laporan Perubahan SLA, Laporan Oprasional, Laporan Perubahan Ekuitas, Neraca, dan Laporan Arus Kas.

Laporan Keuangan Pemerintah Daerah merupakan informasi yang memuat data sebagai elemen struktur kekayaan dan stuktur finansial merupakan pencerminan hasil aktifitas ekonomi suatu organisasi pemerintah daerah. Adapun tujuan Laporan Keuangan Daerah adalah untuk menyajikan informasi yang berguna untuk pengambilan keputusan dan untuk menunjukan akuntabilitas entitas laporan atas sumber daya yang dipercayakan kepadanya.

\section{Kerangka Pikir}

Penelitian ini disusun dengan kerangka pikir sebagai berikut :

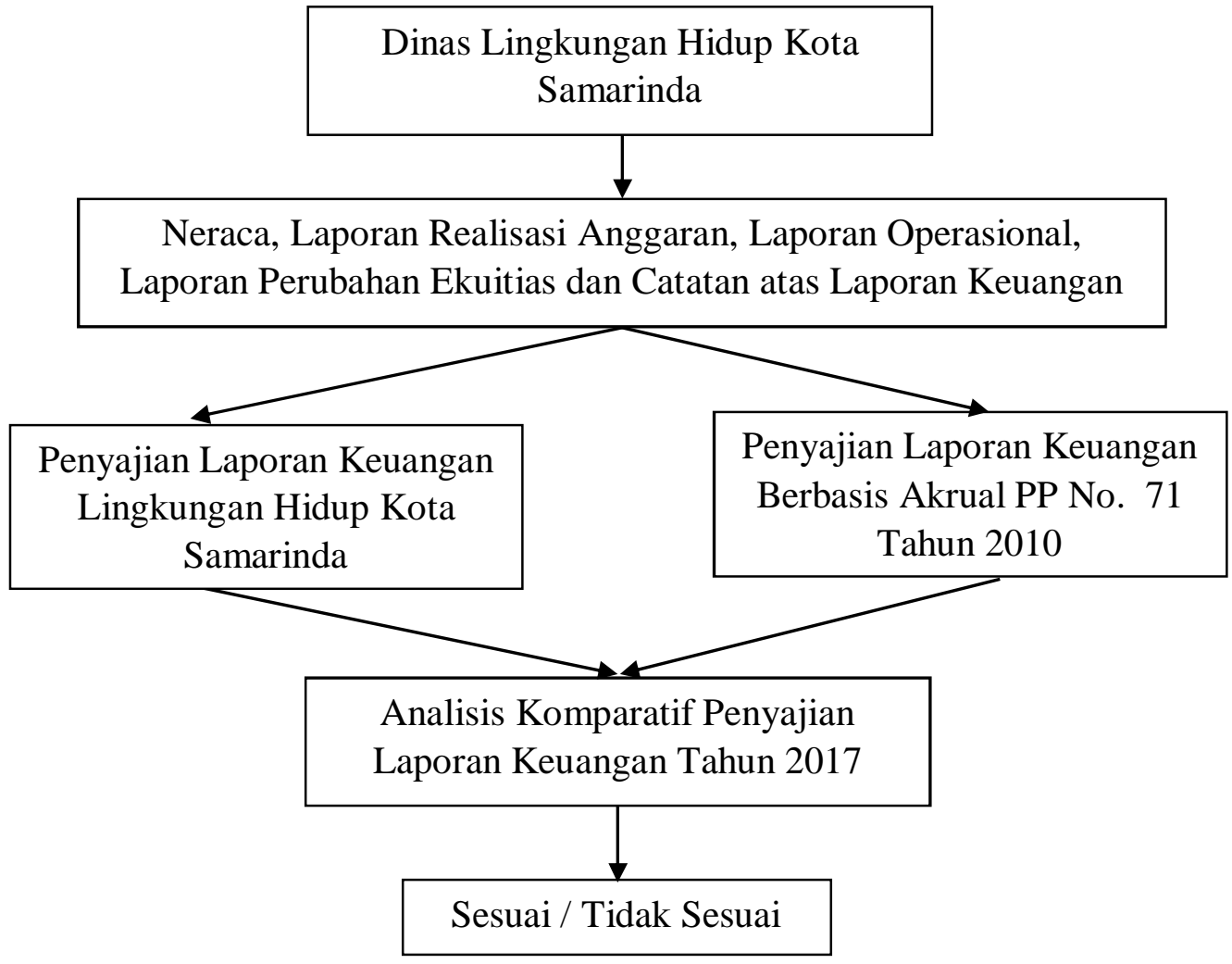




\section{METODE PENELITIAN}

Penelitian ini bersifat deskriptif. Penelitian ini dilakukan pada Dinas Lingkungan Hidup Kota Samarinda, khususnya tentang penyajian Laporan Keuangan Dinas Lingkungan Hidup Kota Samarinda tahun 2017 meliputi: Neraca, Laporan Realisasi Anggaran Laporan Operasional, Laporan Perubahan Ekuitias dan Catatan Atas Laporan Keuangan. Teknik pengumpulan data yang digunakan dalam penelitian ini adalah wawancara, kuesioner dan observasi.

Teknik analisis yang digunakan adalah analisis deskriptif untuk mendeskripsikan penyajian laporan keuangan pada Dinas Lingkungan Hidup Kota Samarinda dan membandingkannya dengan ketentuan yang termaktup dalam Standar Akuntansi Pemerintahan Berbasis Akrual berdasarkan PP No.71 Tahun 2010. Selanjutnya untuk menyatakan kategori kesesuaian digunakan rumus Champion berikut ini :

$$
\text { Presentase }=\frac{\sum \text { Jumlah Jawaban "Ya" }}{\sum \text { Total Jawaban Cheklist }} \times 100 \% \quad \text { Dengan klasifikasi }
$$

kriteria dibawah ini :

Tabel 1 Klasifikasi Kriteria

\begin{tabular}{|l|l|}
\hline \multicolumn{1}{|c|}{ Presentase } & \multicolumn{1}{c|}{ Kriteria } \\
\hline $0 \%-25 \%$ & Dikategorikan Tidak Sesuai \\
\hline $26 \%-50 \%$ & Dikategorikan Kurang Sesuai \\
\hline $51 \%-75 \%$ & Dikategorikan Cukup Sesuai \\
\hline $76 \%-100 \%$ & Dikategorikan Sangat Sesuai \\
\hline
\end{tabular}

Sumber : Dean J. Champion (1990:302)

\section{ANALISIS DAN PEMBAHASAN}

Analisis dan pembahasan dalam penelitian ini dilakukan untuk mencari perbandingan penyajian laporan keuganan Dinas Lingkungkan Hidup Kota Samarinda Tahun 2017 yang terdiri dari Laporan Neraca, Laporan Realisasi Anggaran, Laporan Operasional, Laporan Perubahan Ekuitas dan Catatan Atas Laporan Keuangan dengan PSAP berdasarkan Peraturan Pemerintah No 71 Tahun 2010.

Berdasarkan alat analisis yang telah diuraikan, maka dapat disajikan komparasi nilai kriteria Neraca dan PP No 71 Tahun 2017 dan temuan penelitian sebagai berikut :

1. Pos-pos laporan neraca berupa asset lancar, asset tetap, dana cadangan, asset lainnya, kewajiban jangka pendek, kewajiban ekuitas pada kantor Dinas Lingkungan Hidup Samarinda telah dilakukan sesuai dengan 
Standar Akuntansi Pemerintahan Berbasis Akrual berdasarkan PP No.71 Tahun 2010. Hal ini tergambar dari Hasil perhitungan cheklist komponen laporan keuangan sebesar : $12 / 12 \times 100 \%=100 \%$. Merujuk pada kriteria Jean D Champion terkategori sangat sesuai.

2. Realisasi Anggaran Dinas Lingkungan Hidup Kota Samarinda

Pos-pos Realisasi Anggaran seperti : pendapatan -LRA, Belanja, Transfer, Surplus/deficit -LRA, Pembiayaan, Sisa Lebih/Kurang Pembiayaan Anggaran pada kantor Dinas Lingkungan Hidup Samarinda telah dilakukan sesuai dengan Standar Akuntansi Pemerintahan Berbasis Akrual berdasarkan PP No.71 Tahun 2010. Hal ini tergambar dari Hasil perhitungan cheklist komponen laporan keuangan sebesar : $6 / 6 \times 100 \%=$ $100 \%$. Merujuk pada kriteria Jean D Champion terkategori sangat sesuai.

3. Analisis Laporan Operasional Dinas Lingkungan Hidup Kota Samarinda Pos-pos Laporan Operasional seperti :Pendapatan Laporan Operasional, Beban dari kegiatan operasional,Aset tetap, Surplus/Defisit, Pos Luar Biasa, Transfer Pemerintah Pusat-Dana Perimbangan, Transfer Pemerintah Propinsi pada kantor Dinas Lingkungan Hidup Samarinda telah dilakukan sesuai dengan Standar Akuntansi Pemerintahan Berbasis Akrual berdasarkan PP No.71 Tahun 2010. Hal ini tergambar dari Hasil perhitungan cheklist komponen laporan keuangan sebesar : $8 / 8 \times 100 \%=$ $100 \%$. Merujuk pada kriteria Jean D Champion terkategori sangat sesuai.

4. Analisis Laporan Perubahan Ekuitas Dinas Lingkungan Hidup Kota Samarinda

Pos-pos Laporan Perubahan Ekuitas seperti :Ekuitas, Surplus/Defisit Laporan Operasional,Koreksi Nilai Persediaan,Selisih Revaluasi Aktiva tetap dan Ekuitas Akhir pada kantor Dinas Lingkungan Hidup Samarinda telah dilakukan sesuai dengan Standar Akuntansi Pemerintahan Berbasis Akrual berdasarkan PP No.71 Tahun 2010. Hal ini tergambar dari Hasil perhitungan cheklist komponen laporan keuangan sebesar : 5/5x 100\% $=100 \%$. Merujuk pada kriteria Jean D Champion terkategori sangat sesuai.

5. Analisis Catatan atas Laporan Keuangan Dinas Lingkungan Hidup Kota Samarinda

Pos-pos Catatan Atas Laporan Keuangan seperti : Laporan Realisasi Anggaran, Neraca, Laporan Operasional dan Laporan Perubahan Ekuitas pada kantor Dinas Lingkungan Hidup Samarinda telah dilakukan sesuai dengan Standar Akuntansi Pemerintahan Berbasis Akrual berdasarkan PP No.71 Tahun 2010. Hal ini tergambar dari Hasil perhitungan cheklist komponen laporan keuangan sebesar : $4 / 4 \times 100 \%=100 \%$. Merujuk pada kriteria Jean D Chmpion terkategori sangat sesuai. 
Berdasarkan hasil perhitungan penyajian laporan keuangan pada pospos Catatan atas Laporan Keuangan yang disajikan oleh Dinas Lingkungan Hidup Kota Samarinda dapat disimpulkan bahwa hasilnya berada pada ketogori sangat sesuai sebesar 100 \% berdasarkan PP Nomor 71 Tahun 2010

\section{PENUTUP}

\section{A. Kesimpulan}

1. Neraca yang disajikan pada Dinas Lingkungan Hidup Kota Samarinda masuk dalam kategori sangat sesuai dengan PP Nomor 71 Tahun 2010

2. Laporan Realisasi Anggaran yang disajikan pada Dinas Lingkungan Hidup Kota Samarinda masuk dalam kategori sangat sesuai dengan PP Nomor 71 Tahun 2010

3. Laporan Operasional yang disajikan pada Dinas Lingkungan Hidup Kota Samarinda masuk dalam ketegori sangat sesuai dengan PP Nomor 71 Tahun 2010.

4. Laporan Perubahan Ekuitas yang disajikan pada Dinas Lingkungan Hidup Kota Samarinda masuk dalam kategori sangat sesuai dengan PP Nomor 71 Tahun 2010.

5. Penyajian pos-pos yang disajikan dalam Catatan atas Laporan Keuangan pada Dinas Lingkungan Hidup Kota Samarinda masuk dalam kategori sangat sesuai dengan PP Nomor 71 Tahun 2010.

\section{B. Saran}

Berdasarkan kesimpulan penelitian, maka Dinas Lingkungan Hidup Kota Samarinda tetap menerapkan penyajian pos-pos Neraca, Laporan Realisasi Anggaran, Laporan Operasional, Laporan Perubahan Ekuitas, dan Catatan atas Laporan Keuangan yang disesuaikan dengan PP Nomor 71 Tahun 2010, agar penyajian laporan keuangan Dinas Lingkungan Hidup Kota Samarinda tersebut relevan yang bermanfaat untuk pengguna laporan keuangan dalam memahami informasi-informasi pada laporan keuangan tersebut.

\section{DAFTAR PUSTAKA}

Akbar, Bahrullah. 2013. Akuntansi Pemerintahan. Cetakan 1. Jakarta : CV. Bumi Metro Raya

Anonim, 1966, A Statement of Basic Accounting Theory : Comitee to Prepare a Statement of Basic Accounting Theory. Illinois. USA. 
----------, 2010, Standar Akuntansi Pemerintah Berbasis Akrual : PP Nomor 71 Tahun 2010. KSAP.

Anggalarang, Sulaiman. 2017. Skripsi Evaluasi Efektivitas Pengelolaan Dana Desa Studi Kasus Pada Desa Panggungharjo, Sewon Bantul Daerah Istimewa Yogyakarta. Purwokerto : Fakultas Ekonomi dan Bisnis Universtas Jenderal Soedirman.

Arif, Bachtiar dkk. 2010. Akuntansi Pemerintahan. Jakarta : Salemba Empat.

Bastian, Indra. 2010. Akuntansi Sektor Publik. Edisi Ketiga, Erlangga, Yogyakarta

Champion, Dean J. 1990. Basic Statistic For Socian Research. Adition, New York Mac Media

Charles T.Horngren dan Walter T.Harrison. 2012. Akuntansi jilid Satu, Edisi Tujuh. Jakarta : Penerbit Erlangga.

Halim, Abdul. 2012. Akuntansi Keuangan Daerah, Edisi Keempat. Jakarta : Selemba Empat.

Harahap, Sofyan Safri. 2013. Teori Akuntansi, Edisi Ketiga Belas. Jakarta : Rajawali Pers.

Ismail, Muhammad, Ari Kuncara Widagdo, dkk. 2016. Sistem Akuntansi Pengelolaan Dana Desa. Jurnal Ekonomi dan Bisnis, Vol. XIX No.2, Agustus 2016, ISSN 1979-6471.

Jones Rowan and Pendlebury Maurice. 2010. Public Sector Accounting $6^{\text {th }}$ Edition. England : Pearson Prentice Hall

Mardiasmo. 2009. Akuntansi Sektor Publik, Andi Offset, Yogyakarta : ANDI

Munawir. 2010. Analisis Laporan Keuangan, Edisi Keempat. Yogyakarta : Liberty.

Mursyidi. 2013. Akuntansi Pemerintahan di Indonesia. Cetakan Kedua. Bandung : PT. Refika Aditama

Najmudin. 2011. Manajemen Keuangan Dan Aktualisasi Syariyyah Modern. Yogyakarta : Andi Publisher

Sadeli, Lili. 2014. Dasar Dasar Akuntansi. Jakarta : Bumi Aksara

Sirait. Pirmatua, 2014. Pelaporan dan Laporan Keuangan. Yogyakarta : Penerbit Graha Ilmu

Stice, James D. 2009. Akuntansi Keuangan Intermediate Accounting. Jakarta : Salemba Empat. 
Triharta, A.B. 2013. Sistem Akuntansi Pemerintahan Basis Akrual dengan Entri Berpasangan. Dilampiri dengan Lampiran I PP 71 Tahun 2010. Cetakan Pertama. Yogyakarta : Graha Ilmu 